\title{
CEsifo \\ WORKING

\section{Do Left-Wing Governments Decrease Wage Inequality among Civil Servants? Empirical Evidence from the German States}

Björn Kauder, Manuela Krause, Niklas Potrafke 


\section{Impressum:}

CESifo Working Papers

ISSN 2364-1428 (electronic version)

Publisher and distributor: Munich Society for the Promotion of Economic Research - CESifo

$\mathrm{GmbH}$

The international platform of Ludwigs-Maximilians University's Center for Economic Studies and the ifo Institute

Poschingerstr. 5, 81679 Munich, Germany

Telephone +49 (0)89 2180-2740, Telefax+49 (0)89 2180-17845, email office@cesifo.de

Editor: Clemens Fuest

https://www.cesifo.org/en/wp

An electronic version of the paper may be downloaded

- from the SSRN website: www.SSRN.com

- from the RePEc website: $\quad$ www.RePEc.org

- from the CESifo website: https://www.cesifo.org/en/wp 


\title{
Do Left-Wing Governments Decrease Wage Inequality among Civil Servants? Empirical Evidence from the German States
}

\begin{abstract}
We investigate whether left-wing governments decrease wage inequality among civil servants. The data is based on salaries of civil servants in the German states. Since a reform in 2006, German state governments are allowed to design salaries of civil servants. We employ encompassing data for pay levels and professions including judges, professors, policemen, and administrators and distinguish between levels of operating experiences. We use six wage inequality measures comparing salaries across pay levels and operating experiences. The results do not suggest that left-wing governments were more active in decreasing wage inequality among civil servants than center or right-wing governments. Cabinet members are civil servants themselves and decide on their own salaries: government ideology is also not shown to predict salaries of cabinet members. Because left-wing governments are perceived as taking action against income and wage inequality, future research should employ data from other federal states such as the United States to examine how government ideology influences salaries of civil servants.
\end{abstract}

JEL-Codes: D720, H700, A130, P160.

Keywords: wage inequality, civil servants, government ideology, partisan politics, German states.

Björn Kauder

German Economic Institute

Cologne / Germany

kauder@iwkoeln.de
Manuela Krause

German Economic Institute

Cologne / Germany

KrauseM@dzsf.bund.de

Niklas Potrafke*

ifo Institute - Leibniz Institute for Economic Research

at the University of Munich / Germany

potrafke@ifo.de

*corresponding author

November 2020

This paper has been accepted for publication in the Public Finance Review. 


\section{Introduction}

Income inequality has decreased between countries but is still pronounced within many countries. Scholars examine what influences income inequality across and within countries. A prominent example is globalization (Dreher and Gaston 2008, Bergh and Nilsson 2010, Dorn, Fuest, and Potrafke 2017, Lang and Mendes Tavares 2018). Clearly, domestic governments have a hard time to prevent globalization influencing income inequality, especially when they wish to enjoy benefits of globalization and do not protect their economies from trade and foreign investment flows. Domestic governments may well, however, respond to globalization and its effects on income inequality by implementing policies such as increasing social expenditure, regulating labor markets, and increasing taxes for high-income citizens. ${ }^{1}$ The extent to which domestic governments wish to address income inequality and be active in income redistribution is likely to depend on government ideology. Left-wing governments are expected to be more active in income redistribution to decrease income inequality than right-wing governments. Empirical evidence shows that top income shares increased under right-wing governments more rapidly than under left-wing governments (Scheve and Stavasage 2009, Dorn and Schinke 2018). The previous studies examining how government ideology influences income inequality used panel data for OECD countries and univariate times series for individual OECD countries.

We examine how government ideology influences within-country wage inequality among civil servants. We employ new data on civil servants' salary scales that encompass variation across pay levels and operating experiences. The sample includes salaries of all types of civil servants in the German states: judges, professors, policemen, administrators etc. We elaborate on a reform of the German fiscal constitution in 2006: the reform allowed German state governments to design salaries of civil servants. State governments thus have a direct measure at hand to influence wage inequality among civil servants. The results do not suggest that left-wing governments were more active in decreasing wage inequality among civil servants than center or right-wing governments. 


\section{Background and Hypothesis}

\subsection{Government Ideology and Income and Wage Redistribution}

Left-wing governments are expected to increase the size and scope of governments and, in turn, to decrease income and wage inequality. The partisan theories describe that both left-wing and right-wing governments gratify the needs of their constituencies (Hibbs 1977, Chappell and Keech 1986, Alesina 1987). Blue-collar workers, low-income, and low-skilled citizens have been the constituency of left-wing parties, and self-employed, high-income, and high-skilled citizens have been the constituency of right-wing parties for a long time. The partisan theories modelled the economy by a Phillips-curve tradeoff: politicians use fiscal and monetary policies to choose between unemployment and inflation. Left-wing governments that cater the interests of low-income citizens will implement expansionary fiscal and monetary policies to keep unemployment low (and accept inflation). Right-wing governments cater the interests of high-income citizens; they will implement restrictive fiscal and monetary policies to keep inflation at low rates (and accept unemployment).

The partisan theories have been translated to many economic policy fields; the core hypothesis to be investigated being that left-wing governments increase the size and scope of government which includes income redistribution from high-income to lowincome citizens (for surveys see Schmidt 1996, Potrafke 2017 and 2018, Zohlnhöfer, Engler, and Dümig 2018). Governments have manifold measures at hand to redistribute income from high-income to low-income citizens. An important measure is to tax high-income citizens to a large extent. Taxing high-income citizens incorporates progressive income taxation. Marginal tax rates should be much higher for high than for low incomes, and governments may well grant generous tax-exempt amounts for low incomes. Because high-income citizens often enjoy pronounced capital incomes, governments advocating income redistribution are likely to tax capital more progressively than labor. Low-income citizens usually spend a large amount of their income for consumption. One would therefore expect that left-wing governments are less active in increasing consumption tax rates than right-wing governments. Empirical evidence for OECD countries tends to confirm ideology- 
induced tax policies (e.g., Angelopoulos, Economides, and Kammas 2012, Osterloh and Debus 2012).

Income redistribution also includes generous transfers to low-income citizens. A prominent example is social policies. Left-wing governments may want to promote social insurance against risks such as illness, old age, and unemployment to attract poorer voters and voters with larger health risks (De Donder and Hindriks 2007). Encompassing social insurance gives rise to increasing social expenditure. Scholars have examined how government ideology influences social expenditure. The empirical evidence for OECD countries suggests that social expenditure was higher under left-wing governments until the end of the 1980s; government ideology retired to the background in the 1990s and early 2000s. New studies report ideology-induced social policies, the fields of social policy (health, old age, active labor market policies etc.) notwithstanding. ${ }^{2}$

Pronounced social spending and progressive taxation under left-wing governments accompanied decreasing income inequality. The studies by Scheve and Stavasage (2009) and Dorn and Schinke (2018) show that top income shares were higher under right-wing than under left-wing governments. ${ }^{3}$ The governments of Margaret Thatcher in the United Kingdom and Ronald Reagan in the United States were prime examples for market-oriented policies in the 1980s. The policies included deregulation of labor and product markets, privatizations of state-owned companies and cutting social expenditure and tax reliefs especially for high-income citizens. The top one percent income share started to drastically increase when Thatcher and Reagan came into power. After the 1980s, however, government ideology was not related with top income shares in Anglo-Saxon countries, but in many other OECD countries.

We expect left-wing governments to be more active in reducing income and wage inequality than center and right-wing governments. 


\subsection{Ideology-Induced Policies in the German States}

Examining ideology-induced income and wage redistribution - especially within countries - requires some more fine-grained data than previous studies used. We focus on the German states in which government ideology has been shown to influence economic policies.

German state governments have room to maneuver in individual policy fields such as education and cultural policies. Right-wing governments spent more on universities and somewhat less on primary schools and were more active in introducing tuition fees than left-wing governments (Oberndorfer and Steiner 2007, Potrafke 2011, Kauder and Potrafke 2013). ${ }^{4}$ Law and order policies were influenced by government ideology: right-wing governments hired more policemen and used dragnet-controls controls of persons conducted by the police without having any suspicion that the controlled person committed a crime - more often than left-wing governments (Tepe and Vanhuysse 2013, Potrafke 2020). Government ideology influenced the spatial distribution of health care infrastructure. Left-wing governments shifted hospital infrastructure from rural to urban regions (Potrafke and Roesel 2020). Hospital efficiency was larger and hospitals' capital stocks were higher under right-wing than left-wing governments (Karmann and Roesel 2017, Pilny and Roesel 2020).

German state governments have hardly any means in designing tax policies. An exception is the real-estate transfer tax: the fiscal constitution was reformed in 2006 and allowed state governments to set real-estate transfer tax rates. Empirical evidence shows that left-wing and center governments were more active in increasing the realestate transfer tax rates than right-wing governments (Krause and Potrafke 2020). Left-wing governments that increase real-estate transfer tax rates may well be inclined to redistribute income from high-income to low-income citizens because high-income citizens are more likely to buy properties than low-income citizens and, in turn, pay real-estate transfer taxes.

Left-wing governments may well use salaries of public employees to redistribute incomes and wages: salaries of low-skilled public employees are expected to increase 
to a larger extent than salaries of high-skilled public employees. Especially well-paid public employees are judges and cabinet members of state governments (in Germany, all of them are civil servants and enjoy also other benefits such as entitlements to a pension). Many well-paid public employees receive high salaries in old age, when retirement is close. A reason is experience and networking that are required for job promotion. Another reason is that salaries of public employees mechanically increase - without any job promotion - over time. The German law rewards operating experience. Low-paid public employees do services in the administration such as errands. Clearly, many low-paid public employees are young and therefore receive quite low salaries because they are both grouped into a low pay level and do not have much operating experience yet. It is conceivable that low-paid public employees are likely to vote for left-wing parties that may want to increase entry-level salaries. In a similar vein, well-paid public employees are likely to vote for right-wing parties that are, in turn, inclined to further reward well-paid public employees.

State governments have many means to influence income and wage redistribution among public employees. First, governments design the vertical distribution of pay levels by changing, for example, the relation between salaries of a judge in a local court and a chief judge in the supreme court. Second, governments design the horizontal distribution of pay levels by changing, for example, the relation between salaries of a judge in a local court with two and thirty years of operating experience.

We expect left-wing governments to compress the distribution of salaries of public employees more than right-wing governments. We also expect left-wing governments to increase entry-level salaries more than top salaries.

\section{Institutional Backdrop}

\subsection{Salaries of Civil Servants}

In September 2006, a large reform of German federalism took effect. One of the key elements of the reform was the decision that state parliaments are allowed to set salaries of their civil servants. Before the reform, the salaries of all German civil 
servants were decided on at the federal level. The first state that set its own salaries was Bavaria in 2007. Most other states followed in 2008.

In all states, civil servants are paid based on five pay-level groups (see Table 1). Most civil servants are paid on the A-level, upper-level civil servants on the B-level, professors on the C- and the W-level, and judges and prosecutors on the R-level. Within each of these groups there are different individual pay levels. For example, Alevel civil servants are paid a salary on the levels A2 to A16 and R-level civil servants on the levels R1 to R10. Within each of these pay levels, there are in turn different levels of operating experience. C-level civil servants, for example, are categorized into up to 15 different levels of operating experience.

State governments exploit their decision-making power and differ from each other in designing their civil servants' salary scales. In 2018, for example, the lowest salary in a state varied between 1965 euros (in Lower Saxony) and 2272 euros (in Hamburg); the highest salary in a state varied between 12,510 euros (in Rhineland-Palatinate) and 13,805 euros (in Saxony).

The state governments employ civil servants with a public law contract and public employees with a private law contract (“Tarifangestellte im öffentlichen Dienst”). Therefore, one may also want to examine how government ideology influences wage inequality among public employees. The wage agreements for public employees do, however, not vary across the German states. The exception is Hesse that uses a wage agreement for public employees that differs from the wage agreement for public employees in the other 15 German states.

\subsection{The German Political Party Landscape}

Two major political parties have characterized the political landscape in Germany: the leftist Social Democratic Party (SPD) and the conservative Christian Democratic Union (CDU; in Bavaria CSU). All federal chancellors and state prime ministers except the green prime minister of Baden-Wuerttemberg elected in 2011 and the prime minister of Thuringia from the Left Party elected in 2014 - were members of 
one of these two parties, SPD and CDU. We can therefore test for ideology-induced policy making on a left-right scale.

The Free Democratic Party (FDP) and the Greens (Bündnis 90/Die Grünen) - both much smaller - have played an important role as coalition partners in the West German states, the Left Party (Die Linke) as coalition partner in the East German states.

\section{Empirical Analysis}

\subsection{Empirical Strategy}

State governments decide on increasing salaries of civil servants quite erratically, at seemingly arbitrary points in time. Only in some cases, state governments increase salaries regularly year after year. State governments also often decide on multiple salary increases at the same time. Many decisions include, for example, an increase with retroactive effect from the beginning of the current year, and two increases effective from the beginning of the next year and the beginning of the year after the next year. This erratic pattern makes it infeasible to estimate panel data models using annual data on salary increases. Following Schmitt (2016), we thus condense our data and examine legislative periods.

The baseline panel-data model has the following form:

\section{Change in measure of salariesi, $t=$}

$\beta$ Government ideologyi, $t+\gamma$ Seat share governmenti, $t+\delta$ l.Average age of populationi,t

$+\varepsilon$ 1.Increase in employee salariesi, $t+\zeta$ 1.Increase in Gini of employee salariesi, $t$ $+\theta$ 1.Increase in debt/GDPi,t $+\varphi$ 1.Increase in civil servants p.c.i,t

$+\psi$ 1. Change in measure of salaries (federal) $i, t+\eta i+\tau t+u i, t$

with $i=1, \ldots, 16 ; t=2007, \ldots, 2017$ (median year of legislative period; unbalanced) 
where Change in measure of salariesi,t describes six measures of average annual growth in inequality and two different measures of nominal salaries' growth in state $i$ in the legislative period with median year $t$. Table 1 shows one of the 225 salary scales in our data set as an example. We use all salary scales passed by an individual government to calculate the growth or growth in inequality per year of a legislative period. The individual rows show different pay levels, and the individual columns show different levels of operating experience. Increase in diagonal inequalityi,t is a cross-section type of inequality measure and describes the growth rate of the relation between the highest and the lowest salary in a salary scale. Increase in vertical inequalityi, $t$ describes the growth rate of the relation between the highest and the lowest salary among those civil servants that have reached the highest level of operating experience (technically speaking: the growth rate of the relation between the highest and the lowest row maximum). It is thus an individual-specific measure of inequality, because all civil servants will basically reach the highest level of operating experience at some time. We conjecture the effects of ideology or lobbying to be most clearly reflected in vertical inequality. Increase in horizontal inequalityi, $t$ first calculates the relation between the salaries of the highest and of the lowest level of operating experience for every individual pay level, and then calculates the average of the resulting relations. The measure describes the extent to which experience is remunerated and thus reflects the preferences of a government over intergenerational inequality. Increase in horizontal inequality (weighted)i,t follows the same idea, does however weight the individual pay scales according to the number of civil servants in these pay scales. ${ }^{5}$ Increase in ratio of vertical and horizontal inequalityi, $t$ examines the relative preferences of a government between vertical and horizontal inequality. Increase in Gini coefficienti,t describes how the Gini coefficient of salaries has increased. Information on the number of civil servants in the individual levels of operating experience is not available. The measure thus assumes that all civil servants have reached the highest level of operating experience, and again uses weights for the number of civil servants in the individual pay scales. Average growth of salariesi, $t$ describes the average of the growth rates of the mean salaries in the individual pay scales (note that calculating growth rates of all cells in 
the salary scale individually is not feasible, because the number of levels of operating experience changes quite often). Average growth of salaries (weighted)i,t alters this measure by using weights of the number of civil servants in the individual pay scales when calculating the average.

The variable Government ideologyi, $t$ measures ideology-induced policy making and takes on the value 1 when a left-wing government is in office, the value 0.5 for a center government, and the value 0 for a right-wing government (e.g., Kauder and Potrafke 2013, Potrafke, Riem, and Schinke 2016). In alternative specifications, we also use dummy variables for left-wing, center, and right-wing governments, because the government ideology index assumes a linear relationship between the individual types of governments. We expect that left-wing governments decrease inequality. The effect of government ideology on the growth of salaries is however not clear. Leftwing governments prefer a larger size of government than do right-wing governments and should thus increase salaries more. Some civil servants, such as judges, are however not core constituencies of left-wing governments and should thus not be expected to enjoy large increases in salaries. It is conceivable that politicians increase salaries for civil servants more when their party holds a large majority of seats in parliament (see Benito et al. 2014, Svaleryd and Vlachos 2009). Seat share governmenti, thus measures the number of seats the governing parties have relative to all seats in parliament.

We include six control variables that we measure with a lag of one year. For example, if a legislative period lasts from March 2011 through March 2016, we consider the control variable in the period from March 2010 through March 2015. ${ }^{6}$ l.Average age of populationi,t measures the average age in the population. It is conceivable that governments adjust horizontal inequality when the age composition of the population has changed. All further variables are calculated as per year of the legislative period's length. 1.Increase in employee salariesi, $t$ measures the extent to which nominal salaries of public- and private-sector employees increased in a state (see also Di Tella and Fisman 2004). We expect the salaries of private- and public-sector employees to be positively correlated with salaries of civil servants. The effect on inequality is 
however theoretically ambiguous. 1.Increase in Gini of employee salariesi, $t$ describes the increase in the Gini coefficient of private- and public-sector employees in a state. Here we expect a positive correlation with inequality of civil servants' salaries, whereas the correlation with the growth of salaries is unclear. The variable 1.Increase in debt/GDPi,t measures how public debt in a state has increased relative to state's GDP. We expect this variable to be negatively correlated with salaries of civil servants because state governments are unlikely to increase salaries of civil servants when public debt is increasing. 1.Increase in civil servants p.c.i,t measures the extent to which the number of state civil servants per capita has increased. The correlation with our dependent variables is theoretically ambiguous. ${ }^{7}$ Finally, we include the dependent variables as measured for salaries of civil servants on the federal level (e.g., the increase in the Gini coefficient of federal civil servants), which may serve as a benchmark for state policy-makers when deciding on the salaries of state civil servants. $\eta i$ is a fixed state effect; $\tau t$ is a fixed time effect (based on the median year of a legislative period; reference category: 2007); ui, tis the error term. We estimate the fixed-effects model with standard errors robust to heteroskedasticity (Huber/White/sandwich standard errors; see Huber 1967, White 1980).

\subsection{Descriptive Statistics}

Figure 1 shows the means of our dependent variables separately for left-wing, center, and right-wing governments. The upper two panels show that in legislative periods with a right-wing government, diagonal and vertical inequality decreased by about 1.6 percent per year. Under left-wing and center governments, by contrast, diagonal and vertical inequality decreased by only about half a percent per year. Horizontal inequality, measuring how much experience is remunerated, and the Gini coefficient show only values smaller than one percent for left-wing, center, and right-wing governments. The panel showing the ratio of vertical and horizontal inequality is like that of diagonal and vertical inequality. The average growth rates of salaries hardly differ between left-wing, center, and right-wing governments. For all types of governments, growth rates are on average about 2.5 to 3 percent. Table 2 shows descriptive statistics. Table 3 contains the correlation coefficients between our main 
variables. The bottom row indicates that left-wing governments were more active in increasing diagonal and vertical inequality, and less active in increasing horizontal inequality, and insofar corroborates the evidence from Figure 1. Our data set includes 50 observations. ${ }^{8}$ Table 4 shows our data sources.

\subsection{Regression Results}

Table 5 shows the regression results of the baseline model when fixed state but no fixed time effects are included. The variable Government ideology does not turn out to be statistically significant in most Columns, it is statistically significant at the ten percent level in Column (5). The coefficient estimate of the variable Government ideology indicates that the growth rate in the ratio of vertical and horizontal civil servant salary inequality increased by around one percentage point when the government ideology variable increased by one point, that is from a right-wing to a left-wing government. Right-wing governments thus prefer to reduce vertical inequality and to increase horizontal inequality, corroborating the evidence from Figure 1.

Some of the control variables help to predict increases in inequality of civil servants' salaries and are statistically significant. The average age of the population, for example, is negatively correlated with the increase in horizontal inequality (Columns 3 and 4), corroborating that experience is less scarce and thus less remunerated in an aging population. Increases in horizontal inequality of civil servants' salaries at the federal level are positively correlated with increases in horizontal inequality of civil servants' salaries at the state level (Column 3). The average growth of salaries at the federal level is also positively correlated with the average growth of salaries at the state level (Columns 7 and 8).

When we include fixed time effects (Table 6), the point estimate of the variable Government ideology in Column (5) remains positive but lacks statistical significance. By contrast, the point estimate of the variable Government ideology in Column (3) renders to be statistically significant at the five percent level indicating that the growth rate in horizontal inequality of civil servants' salaries decreased by around 0.3 
percentage points when the government ideology variable increased by one point, that is from a right-wing to a left-wing government. The estimate of the variable Government ideology in Column (4) does however not suggest that the growth rate in horizontal inequality of civil servants' salaries decreased under left-wing governments once we weight the individual pay scales according to the number of civil servants in these pay scales. In fact, it is positive and slightly fails to be statistically significant at the ten percent level.

Table 7 shows the results when we include dummy variables for left-wing and center governments (reference category: right-wing governments), to allow for a non-linear relationship between the individual types of government ideology. Inferences do not change compared to Table 6 . The dummy variable Ideology left is only statistically significant at the ten percent level when Increase in horizontal inequality is the dependent variable. The dummy variable Ideology center does not turn out to be statistically significant in any specification.

\subsection{Robustness Tests}

We submitted our results to rigorous robustness tests using different specifications of our regressions and different samples. None of these robustness tests indicates any severe fragility in our results.

Ideology-induced policy making has been shown to differ between East and West German states (see, for example, Potrafke 2013 and Kauder, Potrafke, and Schinke 2017). When replicating Table 6 for West German states only, the results do not show that government ideology influenced any of our dependent variables, except for the increase in horizontal inequality (negative and statistically significant at the ten percent level). Running the model only for East German states is not meaningful because of only 15 observations.

We tested whether inferences differ across individual pay-level groups (A, B, C, R, and W) by again replicating Table 6. In pay-level group A (including most civil servants), the variable Government ideology shows a positive and statistically significant effect 
for the weighted increase in horizontal inequality. In pay-level groups $\mathrm{C}$ and $\mathrm{R}$ (including professors, judges, and prosecutors), government ideology is positively associated with the variable Average growth of salaries (both unweighted and weighted, statistically significant at the ten percent level). For the other dependent variables and pay-level groups, government ideology does not turn out to be statistically significant.

In the baseline model, all dependent variables are calculated as per year of the legislative period's length. Replicating Table 6, inferences hardly change when we calculate the dependent variables as per year of how long increases are valid: the effect of government ideology is negative and statistically significant at the five percent level when Increase in horizontal inequality is the dependent variable and positive and statistically significant at the ten percent level when Average growth of salaries is the dependent variable.

\section{Salaries of Cabinet Members}

Why is it that left-wing governments are not shown to be more active in decreasing wage inequality among civil servants than center and right-wing governments? It is conceivable that they have self-interests because all cabinet members are employed as (temporary) civil servants themselves. ${ }^{9}$ Cabinet members receive B10 or B11 salaries (the highest B pay level) plus a percentage premium on top of B10 or B11. The percentage premia are decided by the state parliament in which the parties of the state governments have a majority. ${ }^{10}$ Table 8 shows that there is quite some variation in the percentage premia across the German states. In 2017, for example, the percentage premium in Bremen was actually zero - the only German state which did not grant any premium. In North Rhine-Westphalia, the premium was thirty-three percent for the prime minister. Table 7 shows however also that there is hardly any variation within states. Only in few cases, governments increased or decreased the percentage premium for prime ministers or ministers between 2007 and 2017. Decreases occurred under a right-wing government in Hesse, a left-wing government in Rhineland-Palatinate, a center government in Schleswig-Holstein, and a right-wing 
government in Thuringia. A center government in Thuringia increased salaries of cabinet members. This case study evidence does not suggest that government ideology influenced salaries of cabinet members.

We have also estimated our baseline model excluding the pay levels B10 and B11, and the entire B-level. Inferences regarding the effects of government ideology do not change.

\section{Conclusion}

Left-wing governments favor a large size and scope of government and wish to redistribute income from high-income to low-income citizens. Empirical studies have shown that income redistribution was indeed correlated with government ideology in OECD countries (Scheve and Stavasage 2009, Dorn and Schinke 2018): top income shares increased under right-wing governments. Previous studies ignored, however, income inequality within countries by exploiting, for example, variation across regions or federal states.

We compiled measures of inequality in salaries of civil servants in Germany. State governments design salaries of civil servants since 2007 and decide on how to reward individual professions such as judges, professors, policemen, and administrators. Our results do not suggest that left-wing governments were more active in reducing wage inequality among civil servants than center or right-wing governments. Clearly, civil servants in the German states are unlikely to suffer from poverty. Left-wing governments which would like to redistribute income from rich to poor citizens may therefore put more emphasis on designing policies that attract other citizens than civil servants. In any event, differences among low and high salaries of civil servants are drastic, and left-wing governments have a chance to right away decrease income and wage inequality by designing salaries of civil servants.

A delicate issue is that cabinet members are (temporary) civil servants themselves and cabinet members de facto determine their own salaries. We have therefore examined salaries of cabinet members investigating whether left-wing governments 
are more active in decreasing their own salaries than right-wing governments: government ideology is also not shown to predict salaries of cabinet members. We cannot tell anything on how individual cabinet members spend their salaries. It is possible that left-wing cabinet members do not advocate to decrease their own salaries because they wish to donate money for charity.

We report conditional correlations between government ideology and wage inequality among civil servants. Our econometric model includes many explanatory variables that are likely to be correlated with wage inequality among civil servants and/or government ideology. We cannot rule out omitted variable bias; there may well be other variables that are correlated with wage inequality among civil servants and/or government ideology that are not included in our model. What is more, individual voters might have been unsatisfied with how state governments designed the salaries of civil servants and, in turn, have voted the incumbent state government out of office (reverse causality). It is unlikely, however, and we are not aware of any anecdotal evidence suggesting that civil servants' salaries gave rise to changes in state government ideology. In any event, future research may well examine the nexus between government ideology and wage inequality among civil servants by using more fine-grained empirical techniques. New studies on ideology-induced policies often use regression-discontinuity designs and exploit that governments and individual politicians have been elected with tight vote margins. Another strategy to arrive at causal effects is using instrumental variables for government ideology (see, for example, Lind 2020).

The absence of evidence showing that left-wing governments decreased wage inequality among German civil servants is, of course, not to be generalized among other countries. Future research should therefore employ data from other federal states such as the United States to examine how government ideology influences salaries of civil servants. Against the background of quite polarized political parties and voters in the United States, Democratic state governments may well be more active in decreasing wage inequality among civil servants than Republican state governments. 


\section{Acknowledgements}

We thank Thiess Büttner, Klaus Gründler, Andreas Haufler, T. Scott Findley, Felix Rösel, Christian Johannes Sander, conference participants at the Annual Congress of the International Institute of Public Finance 2020, the Annual Congress of the Verein für Socialpolitik 2020, and two anonymous referees for their helpful comments. Isaac N. Cohen, Christina Dannhorn, Kristin Fischer, and Felix Michalik provided excellent research assistance.

\section{Notes}

${ }^{1}$ On how social expenditure cushions the nexus between globalization and income inequality see Bergh, Mirkina, and Nilsson (2020).

${ }^{2}$ See, for example, Potrafke (2009 and 2017), Bove, Efthyvoulou, and Navas (2017), Herwartz and Theilen (2017), Savage (2019), and Schuknecht and Zemanek (2020).

${ }^{3}$ See Bjørnskov (2008) on the nexus between government ideology, income inequality, and economic growth in developing countries.

${ }^{4}$ Government ideology was also related to vocational education spending in the German counties (Bischoff and Hauschildt 2020).

${ }^{5}$ Data on the number of civil servants in individual pay scales is only available from 2011 through 2016. We thus use the 2011 weights also for all years before 2011, and the 2016 weights also for 2017 and 2018. Weights are identical over all states, also because of data availability.

${ }^{6}$ In this example, the year 2010 enters the calculation with a weight of 9.5/12 (months), and the year 2015 with a weight of 2.5/12 (months), if the legislative period ends and begins in the middle of March. The years 2011-2014 enter with a full weight of 12/12. ${ }^{7}$ Data on the number of civil servants in the individual states is only available until 2016. We thus use the value for 2016 also for 2017.

${ }^{8}$ Note that there is one legislative period in the data set without a decision on salaries (Saarland 2009-2012). We code the date of decision of this non-increase as the exact 
middle of the legislative period. We also included legislative periods that have started, but not yet ended until the end of our data set (February 2018), when either a decision on salaries has already taken place or the period was running for at least one year. ${ }^{9}$ On electoral cycles in salaries of US federal bureaucrats and German state members of parliament see Borjas (1984) and Kauder, Krause, and Potrafke (2018).

${ }^{10}$ There is only one minority government in our sample (North Rhine-Westphalia 2010-2012). To be sure, formally there were further minority governments, which however existed only for quite short periods, after coalition governments failed and new elections were called. 


\section{References}

Alesina, Alberto. 1987. Macroeconomic policy in a two-party system as a repeated game. Quarterly Journal of Economics 102: 651-678.

Angelopoulos, Konstantinos, George Economides, and Pantelis Kammas. 2012. Does cabinet ideology matter for the structure of tax policies? European Journal of Political Economy 28: 620-635.

Benito, Bernardino, Francisco Bastida, Ana-María Ríos, and Cristina Vicente. 2014. The causes of legal rents extraction: Evidence from Spanish municipalities. Public Choice 161: 367-383.

Bergh, Andreas, Irina Mirkina, and Therese Nilsson. 2020. Can social expenditure cushion the inequality effect of globalization? Economics and Politics 32: 104142.

Bergh, Andreas, and Therese Nilsson. 2010. Do liberalization and globalization increase income inequality? European Journal of Political Economy 26: 488-505.

Bischoff, Ivo, and Julia Hauschildt. 2020. Party ideology and vocational education spending: Empirical evidence from Germany. CESifo Economic Studies, forthcoming.

Bjørnskov, Christian. 2008. The growth-inequality association: Government ideology matters. Journal of Development Economics 87: 300-308.

Borjas, George J. 1984. Electoral cycles and the earnings of federal bureaucrats. Economic Inquiry 22: 447-459.

Bove, Vincenzo, Georgios Efthyvoulou, and Antonio Navas. 2017. Political cycles in public expenditure: Butter vs guns. Journal of Comparative Economics 45: 582604.

Chappell, Henry W. Jr., and William R. Keech. 1986. Party differences in macroeconomic policies and outcomes. American Economic Review 76: 71-74.

De Donder, Philippe, and Jean Hindriks. 2007. Equilibrium social insurance with policy-motivated parties. European Journal of Political Economy 23: 624-640.

Di Tella, Rafael, and Raymond Fisman. 2004. Are politicians really paid like bureaucrats? Journal of Law and Economics 47: 477-513.

Dorn, Florian, Clemens Fuest, and Niklas Potrafke. 2017. Globalisation and income inequality revisited. European Commission Discussion Paper 056.

Dorn, Florian, and Christoph Schinke. 2018. Top income shares in OECD Countries: The role of government ideology and globalization. World Economy 41: 24912527.

Dreher, Axel, and Noel Gaston. 2008. Has globalisation increased inequality? Review of International Economics 16: 516-536.

Herwartz, Helmut, and Bernd Theilen. 2017. Ideology and redistribution through public spending. European Journal of Political Economy 46: 74-90. 
Hibbs, Douglas A. Jr. 1977. Political parties and macroeconomic policy. American Political Science Review 71: 1467-1487.

Huber, Peter J. 1967. The behavior of maximum likelihood estimates under nonstandard conditions. In Proceedings of the Fifth Berkeley Symposium on Mathematical Statistics and Probability, Volume 1: Statistics, 221-233. University of California Press. Berkeley, California.

Karmann, Alexander, and Felix Roesel. 2017. Hospital policy and productivity Evidence from German states. Health Economics 26: 1548-1565.

Kauder, Björn, Manuela Krause, and Niklas Potrafke. 2018. Electoral cycles in MPs' salaries: Evidence from the German states. International Tax and Public Finance 25: $981-1000$.

Kauder, Björn, and Niklas Potrafke. 2013. Government ideology and tuition fee policy: Evidence from the German states. CESifo Economic Studies 29: 628-649.

Kauder, Björn, Niklas Potrafke, and Christoph Schinke. 2017. Manipulating fiscal forecasts: Evidence from the German states. FinanzArchiv/Public Finance Analysis 73: 213-236.

Krause, Manuela, and Niklas Potrafke. 2020. The real-estate transfer tax and government ideology: Evidence from the German states. FinanzArchiv/Public Finance Analysis 76: 100-120.

Lang, Valentin F., and Marina Mendes Tavares. 2018. The distribution of gains from globalization. IMF Working Paper 18/54.

Lind, Jo Thori. 2020. Rainy day politics. An instrumental variables approach to the effect of parties on political outcomes. European Journal of Political Economy 61: 101821.

Oberndorfer, Ulrich, and Viktor Steiner. 2007. Generationen- oder Parteienkonflikt? Eine empirische Analyse der deutschen Hochschulausgaben. Perspektiven der Wirtschaftspolitik 8: 165-183.

Osterloh, Steffen, and Marc Debus. 2012. Partisan politics in corporate taxation. European Journal of Political Economy 28: 192-207.

Pilny, Adam, and Felix Roesel. 2020. Are doctors better health ministers? American Journal of Health Economics, forthcoming.

Potrafke, Niklas. 2009. Did globalization restrict partisan politics? An empirical evaluation of social expenditures in a panel of OECD countries. Public Choice 140: 105-124.

Potrafke, Niklas. 2011. Public expenditures on education and cultural affairs in the West German states: Does government ideology influence the budget composition? German Economic Review 12: 124-145.

Potrafke, Niklas. 2013. Economic freedom and government ideology across the German states. Regional Studies 47: 433-449. 
Potrafke, Niklas. 2017. Partisan politics: The empirical evidence from OECD panel studies. Journal of Comparative Economics 45: 712-750.

Potrafke, Niklas. 2018. Government ideology and economic policy-making in the United States-a survey. Public Choice 174: 145-207.

Potrafke, Niklas. 2020. Dragnet-controls and government ideology. Defence and Peace Economics 31: 485-501.

Potrafke, Niklas, Marina Riem, and Christoph Schinke. 2016. Debt brakes in the German states: Governments' rhetoric and actions. German Economic Review 17: 253-275.

Potrafke, Niklas, and Felix Roesel. 2020. The urban-rural gap in healthcare infrastructure: Does government ideology matter? Regional Studies 54: 340-351.

Savage, Lee. 2019. The politics of social spending after the great recession: The return of partisan policy making. Governance 32: 123-141.

Scheve, Kenneth, and David Stavasage. 2009. Institutions, partisanship, and inequality in the long run. World Politics 61: 215-253.

Schmidt, Manfred G. 1996. When parties matter: A review of the possibilities and limits of partisan influence on public policy. European Journal of Political Research 30: 155-186.

Schmitt, Carina. 2016. Panel data analysis and partisan variables: How periodization does influence partisan effects. Journal of European Public Policy 23: 1442-1459.

Schuknecht, Ludger, and Holger Zemanek. 2020. Public expenditures and the risk of social dominance. Public Choice, forthcoming.

Svaleryd, Helena, and Jonas Vlachos. 2009. Political rents in a non-corrupt democracy. Journal of Public Economics 93: 355-372.

Tepe, Markus, and Pieter Vanhuysse. 2013. Cops for hire? The political economy of police employment in the German states. Journal of Public Policy 33: 165-199.

White, Halbert. 1980. A heteroskedasticity-consistent covariance matrix estimator and a direct test for heteroskedasticity. Econometrica 48: 817-838.

Zohlnhöfer, Reimut, Fabian Engler, and Kathrin Dümig. 2018. The retreat of the interventionist state in advanced democracies. British Journal of Political Science 48: 535-562. 
Table 1: Example of a salary scale (North Rhine-Westphalia 2012)

\begin{tabular}{|c|c|c|c|c|c|c|c|c|c|c|c|c|c|c|c|c|}
\hline \multirow{2}{*}{$\begin{array}{l}\text { Pay } \\
\text { level }\end{array}$} & \multicolumn{16}{|c|}{ Operating experience } \\
\hline & 0 & 1 & 2 & 3 & 4 & 5 & 6 & 7 & 8 & 9 & 10 & 11 & 12 & 13 & 14 & 15 \\
\hline A 2 & & 1674.41 & 1713.91 & 1753.43 & 1792.93 & 1832.43 & 1871.97 & 1911.48 & & & & & & & & \\
\hline A 3 & & 1742.65 & 1784.69 & 1826.71 & 1868.75 & 1910.80 & 1952.85 & 1994.89 & & & & & & & & \\
\hline A 4 & & 1781.35 & 1830.86 & 1880.32 & 1929.84 & 1979.33 & 2028.82 & 2078.29 & & & & & & & & \\
\hline A 5 & & 1795.43 & 1858.80 & 1908.05 & 1957.27 & 2006.52 & 2055.75 & 2105.00 & 2154.25 & & & & & & & \\
\hline A 6 & & 1837.04 & 1891.10 & 1945.16 & 1999.23 & 2053.29 & 2107.37 & 2161.43 & 2215.50 & 2269.55 & & & & & & \\
\hline A 7 & & 1916.07 & 1964.67 & 2032.69 & 2100.72 & 2168.76 & 2236.78 & 2304.83 & 2353.39 & 2401.99 & 2450.60 & & & & & \\
\hline A 8 & & & 2033.70 & 2091.82 & 2178.99 & 2266.19 & 2353.35 & 2440.57 & 2498.68 & 2556.79 & 2614.93 & 2673.04 & & & & \\
\hline A 9 & & & 2164.21 & 2221.39 & 2314.44 & 2407.49 & 2500.54 & 2593.59 & 2657.54 & 2721.54 & 2785.49 & 2849.46 & & & & \\
\hline A 10 & & & 2328.95 & 2408.43 & 2527.62 & 2646.86 & 2766.08 & 2885.30 & 2964.77 & 3044.25 & 3123.72 & 3203.19 & & & & \\
\hline A 11 & & & & 2678.78 & 2800.93 & 2923.09 & 3045.25 & 3167.41 & 3248.84 & 3330.28 & 3411.73 & 3493.17 & 3574.61 & & & \\
\hline A 12 & & & & 2878.00 & 3023.64 & 3169.28 & 3314.92 & 3460.55 & 3557.64 & 3654.74 & 3751.83 & 3848.93 & 3946.01 & & & \\
\hline A 13 & & & & 3234.59 & 3391.86 & 3549.14 & 3706.40 & 3863.66 & 3968.51 & 4073.35 & 4178.20 & 4283.06 & 4387.91 & & & \\
\hline A 14 & & & & 3364.87 & 3568.85 & 3772.78 & 3976.72 & 4180.64 & 4316.60 & 4452.57 & 4588.53 & 4724.49 & 4860.46 & & & \\
\hline A 15 & & & & & & & 4369.26 & 4593.48 & 4772.86 & 4952.23 & 5131.63 & 5311.01 & 5490.39 & & & \\
\hline A 16 & & & & & & & 4821.68 & 5080.98 & 5288.47 & 5495.93 & 5703.37 & 5910.85 & 6118.30 & & & \\
\hline B 1 & 5490.39 & & & & & & & & & & & & & & & \\
\hline B 2 & 6380.77 & & & & & & & & & & & & & & & \\
\hline B 3 & 6757.72 & & & & & & & & & & & & & & & \\
\hline B 4 & 7152.52 & & & & & & & & & & & & & & & \\
\hline B 5 & 7605.46 & & & & & & & & & & & & & & & \\
\hline B 8 & 8882.92 & & & & & & & & & & & & & & & \\
\hline B 9 & 9421.37 & & & & & & & & & & & & & & & \\
\hline B 10 & 11093.46 & & & & & & & & & & & & & & & \\
\hline B 11 & 11524.40 & & & & & & & & & & & & & & & \\
\hline C 1 & & 3024.89 & 3129.76 & 3234.59 & 3339.43 & 3444.30 & 3549.14 & 3653.98 & 3758.82 & 3863.66 & 3968.28 & 4073.35 & 4178.20 & 4294.16 & 4387.91 & \\
\hline C 2 & & 3031.44 & 3198.53 & 3365.62 & 3532.73 & 3699.81 & 3866.90 & 4034.00 & 4201.08 & 4368.16 & 4535.27 & 4702.34 & 4869.43 & 5036.52 & 5203.62 & 5370.71 \\
\hline C 3 & & 3334.22 & 3523.41 & 3712.62 & 3901.82 & 4091.01 & 4280.21 & 4469.40 & 4658.58 & 4847.78 & 5036.97 & 5226.16 & 5415.37 & 5604.54 & 5793.75 & 5982.93 \\
\hline C 4 & & 4224.92 & 4415.11 & 4605.29 & 4795.48 & 4985.67 & 5175.85 & 5366.07 & 5556.22 & 5746.41 & 5936.60 & 6126.80 & 6316.97 & 6507.16 & 6697.34 & 6887.53 \\
\hline R 1 & & 3470.86 & 3628.14 & 3710.94 & 3924.50 & 4138.09 & 4351.64 & 4565.21 & 4778.81 & 4992.37 & 5205.94 & 5419.50 & 5633.11 & & & \\
\hline R 2 & & & & 4222.18 & 4435.75 & 4649.31 & 4862.91 & 5076.49 & 5290.04 & 5503.62 & 5717.18 & 5930.77 & 6144.30 & & & \\
\hline R 3 & 6757.72 & & & & & & & & & & & & & & & \\
\hline R 4 & 7152.52 & & & & & & & & & & & & & & & \\
\hline R 5 & 7605.46 & & & & & & & & & & & & & & & \\
\hline R 6 & 8033.20 & & & & & & & & & & & & & & & \\
\hline R 7 & 8449.27 & & & & & & & & & & & & & & & \\
\hline R 8 & 8882.92 & & & & & & & & & & & & & & & \\
\hline R 9 & 9421.37 & & & & & & & & & & & & & & & \\
\hline R 10 & 11570.14 & & & & & & & & & & & & & & & \\
\hline W 1 & 3816.31 & & & & & & & & & & & & & & & \\
\hline W 2 & 4354.02 & & & & & & & & & & & & & & & \\
\hline W 3 & 5278.75 & & & & & & & & & & & & & & & \\
\hline
\end{tabular}

Monthly gross salaries in euros. Source: own illustration 
Table 2: Descriptive statistics

\begin{tabular}{|c|c|c|c|c|c|}
\hline & Obs. & Mean & Std. Dev. & Min & Max \\
\hline Increase in diagonal inequality & 50 & -0.009 & 0.013 & -0.062 & 0.008 \\
\hline Increase in vertical inequality & 50 & -0.009 & 0.014 & -0.062 & 0.008 \\
\hline Increase in horizontal inequality & 50 & 0.001 & 0.003 & -0.003 & 0.015 \\
\hline Increase in horizontal inequality (weighted) & 50 & -0.000 & 0.001 & -0.005 & 0.002 \\
\hline Increase in ratio of vert. and horiz. ineq. & 50 & -0.009 & 0.015 & -0.070 & 0.008 \\
\hline Increase in Gini coefficient & 50 & -0.002 & 0.007 & -0.030 & 0.015 \\
\hline Average growth of salaries & 50 & 0.027 & 0.012 & 0.000 & 0.064 \\
\hline Average growth of salaries (weighted) & 50 & 0.027 & 0.013 & 0.000 & 0.068 \\
\hline Government ideology & 50 & 0.540 & 0.402 & 0.000 & 1.000 \\
\hline Ideology left & 50 & 0.360 & 0.485 & 0.000 & 1.000 \\
\hline Ideology center & 50 & 0.360 & 0.485 & 0.000 & 1.000 \\
\hline Ideology right & 50 & 0.280 & 0.454 & 0.000 & 1.000 \\
\hline Seat share government & 50 & 0.574 & 0.079 & 0.382 & 0.855 \\
\hline 1.Average age of population & 50 & 44.311 & 1.608 & 41.913 & 47.735 \\
\hline 1.Increase in employee salaries & 50 & 0.022 & 0.009 & 0.008 & 0.039 \\
\hline 1.Increase in Gini of employee salaries & 50 & 0.004 & 0.027 & -0.073 & 0.100 \\
\hline 1.Increase in debt/GDP & 50 & 0.001 & 0.052 & -0.081 & 0.246 \\
\hline 1.Increase in civil servants p.c. & 50 & 0.000 & 0.011 & -0.019 & 0.024 \\
\hline 1.Increase in diagonal inequality federal & 50 & -0.008 & 0.014 & -0.045 & 0.015 \\
\hline 1.Increase in vertical inequality federal & 50 & -0.007 & 0.014 & -0.044 & 0.015 \\
\hline 1.Increase in horizontal inequality federal & 50 & -0.003 & 0.006 & -0.018 & 0.001 \\
\hline 1.Increase in horizontal inequality federal (weighted) & 50 & -0.005 & 0.006 & -0.018 & 0.000 \\
\hline 1.Increase in Gini coefficient federal & 50 & 0.013 & 0.017 & -0.002 & 0.053 \\
\hline 1.Average growth of salaries federal & 50 & 0.028 & 0.012 & 0.000 & 0.050 \\
\hline 1.Average growth of salaries federal (weighted) & 50 & 0.030 & 0.012 & 0.000 & 0.053 \\
\hline
\end{tabular}


Table 3: Correlation between the main variables

\begin{tabular}{|c|c|c|c|c|c|c|c|c|c|}
\hline & $\begin{array}{l}\text { Increase } \\
\text { in } \\
\text { diagonal } \\
\text { inequality }\end{array}$ & $\begin{array}{l}\text { Increase } \\
\text { in } \\
\text { vertical } \\
\text { inequality }\end{array}$ & $\begin{array}{l}\text { Increase } \\
\text { in } \\
\text { horizontal } \\
\text { inequality }\end{array}$ & $\begin{array}{c}\text { Increase } \\
\text { in } \\
\text { horizontal } \\
\text { inequality } \\
\text { (weighted) }\end{array}$ & $\begin{array}{l}\text { Increase } \\
\text { in ratio of } \\
\text { vert. and } \\
\text { horiz. } \\
\text { ineq. }\end{array}$ & $\begin{array}{c}\text { Increase } \\
\text { in } \\
\text { Gini } \\
\text { coefficient }\end{array}$ & $\begin{array}{l}\text { Average } \\
\text { growth } \\
\text { of } \\
\text { salaries }\end{array}$ & $\begin{array}{l}\text { Average } \\
\text { growth } \\
\text { of salaries } \\
\text { (weighted) }\end{array}$ & $\begin{array}{l}\text { Government } \\
\text { ideology }\end{array}$ \\
\hline $\begin{array}{l}\text { Increase in diagonal } \\
\text { inequality }\end{array}$ & 1 & & & & & & & & \\
\hline $\begin{array}{l}\text { Increase in vertical } \\
\text { inequality }\end{array}$ & $0.969 * * *$ & 1 & & & & & & & \\
\hline $\begin{array}{l}\text { Increase in horizontal } \\
\text { inequality }\end{array}$ & $-0.573 * * *$ & $-0.537 * * *$ & 1 & & & & & & \\
\hline $\begin{array}{l}\text { Increase in horizontal } \\
\text { inequality (weighted) }\end{array}$ & 0.203 & 0.208 & $0.362^{* * *}$ & 1 & & & & & \\
\hline $\begin{array}{l}\text { Increase in ratio of } \\
\text { vert. and horiz. ineq. }\end{array}$ & $0.971^{* * *}$ & $0.997 * * *$ & $-0.566 * * *$ & 0.175 & 1 & & & & \\
\hline $\begin{array}{l}\text { Increase in Gini } \\
\text { coefficient }\end{array}$ & $0.718^{* * *}$ & $0.666^{* * *}$ & $-0.488^{* * *}$ & 0.127 & $0.712^{* * *}$ & 1 & & & \\
\hline $\begin{array}{l}\text { Average growth of } \\
\text { salaries }\end{array}$ & $-0.256^{*}$ & -0.229 & 0.192 & -0.205 & -0.233 & $-0.317 * *$ & 1 & & \\
\hline $\begin{array}{l}\text { Average growth of } \\
\text { salaries (weighted) }\end{array}$ & $-0.269 *$ & $-0.239 *$ & 0.196 & -0.211 & $-0.242^{*}$ & $-0.338^{* *}$ & $0.994^{* * *}$ & 1 & \\
\hline Government ideology & $0.342^{* *}$ & $0.278^{*}$ & $-0.301 * *$ & 0.024 & $0.285^{* *}$ & 0.211 & 0.022 & 0.003 & 1 \\
\hline
\end{tabular}

\footnotetext{
$* p<0.10,{ }^{* *} p<0.05,{ }^{* * *} p<0.01$
} 
Table 4: Data sources

Salaries of state civil servants

Decision dates (states)

Government ideology

Seat share government

Average age of population

Employee salaries

Gini of employee salaries

Debt

GDP

Number of civil servants (in different pay scales)

Salaries of federal civil servants

Decision dates (federal)
State law gazettes

State law gazettes

Kauder, Krause, and Potrafke (2018)

State election administrators

Federal statistical office

State statistical offices

German Socio-Economic Panel

State statistical offices

State statistical offices

Federal statistical office

Federal law gazettes

Federal law gazettes 
Table 5: Regression results. Including categorical government ideology variable and excluding fixed time effects. Fixed-effects model with standard errors robust to heteroskedasticity (Huber/White/sandwich standard errors)

\begin{tabular}{|c|c|c|c|c|c|c|c|c|}
\hline & (1) & $(2)$ & (3) & (4) & (5) & (6) & $(7)$ & $(8)$ \\
\hline & $\begin{array}{c}\text { Increase in } \\
\text { diagonal } \\
\text { inequality }\end{array}$ & $\begin{array}{l}\text { Increase in } \\
\text { vertical } \\
\text { inequality }\end{array}$ & $\begin{array}{l}\text { Increase in } \\
\text { horizontal } \\
\text { inequality }\end{array}$ & $\begin{array}{l}\text { Increase in } \\
\text { horizontal } \\
\text { inequality } \\
\text { (weighted) }\end{array}$ & $\begin{array}{l}\text { Increase in } \\
\text { ratio of vert. } \\
\text { and horiz. } \\
\text { ineq. }\end{array}$ & $\begin{array}{c}\text { Increase in } \\
\text { Gini } \\
\text { coefficient }\end{array}$ & $\begin{array}{l}\text { Average } \\
\text { growth } \\
\text { of salaries }\end{array}$ & $\begin{array}{l}\text { Average } \\
\text { growth } \\
\text { of salaries } \\
\text { (weighted) }\end{array}$ \\
\hline Government ideology & $\begin{array}{c}0.00796 \\
(0.00479)\end{array}$ & $\begin{array}{c}0.00754 \\
(0.00494)\end{array}$ & $\begin{array}{l}-0.00183 \\
(0.00113)\end{array}$ & $\begin{array}{c}0.000646 \\
(0.000542)\end{array}$ & $\begin{array}{c}0.0102^{*} \\
(0.00490)\end{array}$ & $\begin{array}{c}0.00388 \\
(0.00283)\end{array}$ & $\begin{array}{c}0.00920 \\
(0.00785)\end{array}$ & $\begin{array}{c}0.00698 \\
(0.00812)\end{array}$ \\
\hline Seat share government & $\begin{array}{l}0.00792 \\
(0.0211)\end{array}$ & $\begin{array}{c}0.0120 \\
(0.0204)\end{array}$ & $\begin{array}{c}-0.0131 \\
(0.00871)\end{array}$ & $\begin{array}{c}-0.00602 * * \\
(0.00241)\end{array}$ & $\begin{array}{c}0.0113 \\
(0.0207)\end{array}$ & $\begin{array}{c}-0.0118 \\
(0.00888)\end{array}$ & $\begin{array}{l}0.00406 \\
(0.0313)\end{array}$ & $\begin{array}{l}0.00744 \\
(0.0282)\end{array}$ \\
\hline $\begin{array}{l}\text { 1.Average age of } \\
\text { population }\end{array}$ & $\begin{array}{c}0.00644 \\
(0.00684)\end{array}$ & $\begin{array}{c}0.00604 \\
(0.00667)\end{array}$ & $\begin{array}{c}-0.00204 * \\
(0.00111)\end{array}$ & $\begin{array}{c}-0.000780^{* *} \\
(0.000357)\end{array}$ & $\begin{array}{c}0.00475 \\
(0.00704)\end{array}$ & $\begin{array}{l}0.000273 \\
(0.00244)\end{array}$ & $\begin{array}{l}-0.0114^{*} \\
(0.00643)\end{array}$ & $\begin{array}{c}-0.0101 \\
(0.00608)\end{array}$ \\
\hline $\begin{array}{l}\text { 1.Increase in employee } \\
\text { salaries }\end{array}$ & $\begin{array}{c}0.342 \\
(0.324)\end{array}$ & $\begin{array}{c}0.301 \\
(0.415)\end{array}$ & $\begin{array}{l}0.0259 \\
(0.106)\end{array}$ & $\begin{array}{c}-0.00792 \\
(0.0467)\end{array}$ & $\begin{array}{c}0.213 \\
(0.359)\end{array}$ & $\begin{array}{c}0.323 \\
(0.247)\end{array}$ & $\begin{array}{l}0.0571 \\
(0.583)\end{array}$ & $\begin{array}{c}0.180 \\
(0.556)\end{array}$ \\
\hline $\begin{array}{l}\text { 1.Increase in Gini of } \\
\text { employee salaries }\end{array}$ & $\begin{array}{c}0.0182 \\
(0.0720)\end{array}$ & $\begin{array}{l}0.00947 \\
(0.0744)\end{array}$ & $\begin{array}{c}0.0414^{* *} \\
(0.0171)\end{array}$ & $\begin{array}{l}0.0240^{* * *} \\
(0.00779)\end{array}$ & $\begin{array}{l}-0.0219 \\
(0.0829)\end{array}$ & $\begin{array}{l}-0.0489 \\
(0.0524)\end{array}$ & $\begin{array}{l}-0.0248 \\
(0.0848)\end{array}$ & $\begin{array}{c}-0.00712 \\
(0.0788)\end{array}$ \\
\hline 1.Increase in debt/GDP & $\begin{array}{l}0.0823^{*} \\
(0.0466)\end{array}$ & $\begin{array}{c}0.0736 \\
(0.0475)\end{array}$ & $\begin{array}{l}0.000740 \\
(0.00807)\end{array}$ & $\begin{array}{c}0.00685 \\
(0.00583)\end{array}$ & $\begin{array}{c}0.0529 \\
(0.0486)\end{array}$ & $\begin{array}{c}0.0109 \\
(0.0234)\end{array}$ & $\begin{array}{l}-0.0829 \\
(0.0577)\end{array}$ & $\begin{array}{l}-0.0773 \\
(0.0528)\end{array}$ \\
\hline $\begin{array}{l}\text { 1.Increase in civil } \\
\text { servants p.c. }\end{array}$ & $\begin{array}{l}-0.0698 \\
(0.192)\end{array}$ & $\begin{array}{l}0.0326 \\
(0.167)\end{array}$ & $\begin{array}{l}-0.0189 \\
(0.0417)\end{array}$ & $\begin{array}{c}-0.0549 * \\
(0.0269)\end{array}$ & $\begin{array}{l}0.0368 \\
(0.200)\end{array}$ & $\begin{array}{l}-0.0910 \\
(0.122)\end{array}$ & $\begin{array}{l}0.0125 \\
(0.293)\end{array}$ & $\begin{array}{l}0.0335 \\
(0.272)\end{array}$ \\
\hline $\begin{array}{l}\text { 1.Dependent variable } \\
\text { federal }\end{array}$ & $\begin{array}{l}-0.0139 \\
(0.271)\end{array}$ & $\begin{array}{l}-0.0237 \\
(0.296)\end{array}$ & $\begin{array}{c}0.135^{*} \\
(0.0701)\end{array}$ & $\begin{array}{c}0.0475 \\
(0.0317)\end{array}$ & $\begin{array}{c}0.162 \\
(0.233)\end{array}$ & $\begin{array}{c}0.0982 \\
(0.0745)\end{array}$ & $\begin{array}{l}0.371 * \\
(0.194)\end{array}$ & $\begin{array}{c}0.447 * * \\
(0.181)\end{array}$ \\
\hline Observations & 50 & 50 & 50 & 50 & 50 & 50 & 50 & 50 \\
\hline Groups & 16 & 16 & 16 & 16 & 16 & 16 & 16 & 16 \\
\hline $\mathrm{R}^{2}$ within & 0.423 & 0.356 & 0.443 & 0.442 & 0.370 & 0.298 & 0.326 & 0.396 \\
\hline $\mathrm{R}^{2}$ between & 0.0124 & 0.000144 & 0.0174 & 0.0271 & 0.000269 & 0.0223 & 0.236 & 0.168 \\
\hline $\mathrm{R}^{2}$ overall & 0.148 & 0.0917 & 0.0875 & 0.111 & 0.133 & 0.119 & 0.00102 & 0.0252 \\
\hline
\end{tabular}

Standard errors in parentheses. ${ }^{*} p<0.10,{ }^{* *} p<0.05,{ }^{* * *} p<0.01$ 
Table 6: Regression results. Including categorical government ideology variable and fixed time effects. Fixed-effects model with standard errors robust to heteroskedasticity (Huber/White/sandwich standard errors)

(1)

\begin{tabular}{|c|c|c|c|c|c|c|c|c|}
\hline & $\begin{array}{c}\text { Increase in } \\
\text { diagonal } \\
\text { inequality }\end{array}$ & $\begin{array}{l}\text { Increase in } \\
\text { vertical } \\
\text { inequality }\end{array}$ & $\begin{array}{l}\text { Increase in } \\
\text { horizontal } \\
\text { inequality }\end{array}$ & $\begin{array}{l}\text { Increase in } \\
\text { horizontal } \\
\text { inequality } \\
\text { (weighted) }\end{array}$ & $\begin{array}{l}\text { Increase in } \\
\text { ratio of vert. } \\
\text { and horiz. } \\
\text { ineq. }\end{array}$ & $\begin{array}{c}\text { Increase in } \\
\text { Gini } \\
\text { coefficient }\end{array}$ & $\begin{array}{l}\text { Average } \\
\text { growth } \\
\text { of salaries }\end{array}$ & $\begin{array}{l}\text { Average } \\
\text { growth } \\
\text { of salaries } \\
\text { (weighted) }\end{array}$ \\
\hline \multirow[t]{2}{*}{ Government ideology } & 0.00451 & 0.00299 & $-0.00280^{* *}$ & 0.00117 & 0.00411 & 0.00519 & 0.00681 & 0.00385 \\
\hline & $(0.00575)$ & $(0.00639)$ & $(0.00127)$ & $(0.000695)$ & $(0.00761)$ & $(0.00427)$ & $(0.00403)$ & $(0.00417)$ \\
\hline \multirow[t]{2}{*}{ Seat share government } & 0.0152 & 0.0220 & -0.00826 & $-0.00372 * *$ & 0.0246 & -0.0138 & -0.0198 & -0.00772 \\
\hline & $(0.0177)$ & $(0.0205)$ & $(0.00575)$ & $(0.00138)$ & $(0.0232)$ & $(0.0108)$ & $(0.0220)$ & $(0.0213)$ \\
\hline \multirow{2}{*}{$\begin{array}{l}\text { 1.Average age of } \\
\text { population }\end{array}$} & 0.00287 & 0.00262 & -0.000644 & 0.000127 & 0.00269 & 0.00299 & $-0.0156^{* *}$ & $-0.0128^{* *}$ \\
\hline & $(0.00565)$ & $(0.00604)$ & $(0.000662)$ & $(0.000483)$ & $(0.00589)$ & $(0.00384)$ & $(0.00547)$ & $(0.00599)$ \\
\hline \multirow{2}{*}{$\begin{array}{l}\text { 1.Increase in employee } \\
\text { salaries }\end{array}$} & 0.395 & 0.762 & 0.183 & 0.0716 & 0.736 & 0.0197 & -0.339 & -0.290 \\
\hline & $(0.405)$ & $(0.501)$ & $(0.112)$ & $(0.0422)$ & $(0.614)$ & $(0.329)$ & $(0.452)$ & $(0.498)$ \\
\hline \multirow{2}{*}{$\begin{array}{l}\text { 1.Increase in Gini of } \\
\text { employee salaries }\end{array}$} & 0.0712 & 0.0628 & $0.0413^{* * *}$ & $0.0334 * * *$ & 0.0413 & -0.0430 & -0.0572 & -0.0439 \\
\hline & $(0.0664)$ & $(0.0681)$ & $(0.0121)$ & $(0.00936)$ & $(0.0807)$ & $(0.0447)$ & $(0.0745)$ & $(0.0853)$ \\
\hline \multirow[t]{2}{*}{ 1.Increase in debt/GDP } & -0.00785 & -0.0286 & -0.00356 & -0.00722 & -0.0561 & 0.0120 & 0.0595 & 0.0510 \\
\hline & $(0.0728)$ & $(0.0744)$ & $(0.0130)$ & $(0.00893)$ & $(0.0767)$ & $(0.0455)$ & $(0.0528)$ & $(0.0602)$ \\
\hline \multirow{2}{*}{$\begin{array}{l}\text { 1.Increase in civil } \\
\text { servants p.c. }\end{array}$} & -0.258 & 0.0602 & $0.142^{*}$ & -0.0177 & 0.0369 & $-0.419 *$ & -0.0672 & 0.0532 \\
\hline & $(0.276)$ & $(0.239)$ & $(0.0726)$ & $(0.0397)$ & $(0.254)$ & $(0.211)$ & $(0.312)$ & $(0.341)$ \\
\hline \multirow{2}{*}{$\begin{array}{l}\text { 1.Dependent variable } \\
\text { federal }\end{array}$} & -0.140 & -0.369 & 0.196 & 0.00988 & -0.245 & 0.0172 & $0.556^{*}$ & 0.420 \\
\hline & $(0.384)$ & $(0.455)$ & $(0.112)$ & $(0.0372)$ & $(0.363)$ & $(0.0573)$ & $(0.288)$ & $(0.317)$ \\
\hline \multirow[t]{2}{*}{2008} & 0.0104 & 0.00381 & -0.000941 & -0.00145 & 0.0105 & 0.00888 & 0.0101 & 0.0117 \\
\hline & $(0.0172)$ & $(0.0174)$ & $(0.00298)$ & $(0.000921)$ & $(0.0164)$ & $(0.00957)$ & $(0.0136)$ & (0.0164) \\
\hline \multirow[t]{2}{*}{2009} & 0.0121 & 0.00953 & 0.00294 & $-0.00236^{* *}$ & 0.0163 & -0.00416 & 0.00436 & 0.00674 \\
\hline & $(0.0129)$ & $(0.0140)$ & $(0.00256)$ & $(0.00107)$ & $(0.00940)$ & $(0.00588)$ & $(0.0137)$ & $(0.0156)$ \\
\hline \multirow[t]{2}{*}{2010} & $0.0394^{*}$ & 0.0297 & -0.00491 & -0.000472 & $0.0403^{* *}$ & $0.0163^{*}$ & -0.0167 & -0.0173 \\
\hline & $(0.0189)$ & $(0.0204)$ & $(0.00363)$ & (0.000898) & $(0.0165)$ & $(0.00895)$ & $(0.0127)$ & $(0.0173)$ \\
\hline \multirow[t]{2}{*}{2011} & 0.0294 & 0.0193 & -0.00658 & -0.00171 & 0.0297 & 0.0108 & 0.000445 & 0.00176 \\
\hline & $(0.0230)$ & $(0.0241)$ & $(0.00457)$ & $(0.00102)$ & $(0.0193)$ & $(0.0125)$ & $(0.0140)$ & (0.0191) \\
\hline \multirow[t]{2}{*}{2012} & $0.0391 * * *$ & $0.0427 * *$ & -0.00313 & -0.00133 & $0.0472 * *$ & $0.0201 * *$ & -0.0157 & -0.00631 \\
\hline & $(0.0116)$ & $(0.0151)$ & $(0.00320)$ & (0.000913) & $(0.0164)$ & $(0.00831)$ & $(0.0160)$ & $(0.0161)$ \\
\hline \multirow[t]{2}{*}{2013} & 0.0139 & 0.00417 & $-0.00636^{*}$ & $-0.00506^{* *}$ & 0.00594 & 0.0103 & 0.0179 & 0.0206 \\
\hline & $(0.0127)$ & $(0.0115)$ & $(0.00323)$ & $(0.00224)$ & $(0.0155)$ & $(0.00810)$ & $(0.0156)$ & (0.0188) \\
\hline \multirow[t]{2}{*}{2014} & 0.0137 & 0.00232 & $-0.00566^{*}$ & $-0.00486^{* *}$ & 0.00472 & 0.00363 & $0.0282^{*}$ & 0.0307 \\
\hline & $(0.0162)$ & $(0.0182)$ & $(0.00294)$ & $(0.00180)$ & $(0.0198)$ & $(0.00908)$ & $(0.0160)$ & $(0.0201)$ \\
\hline \multirow[t]{2}{*}{2015} & 0.0264 & 0.0235 & $-0.00518^{* *}$ & $-0.00287^{* *}$ & 0.0271 & 0.00238 & 0.0173 & 0.0197 \\
\hline & $(0.0158)$ & $(0.0168)$ & $(0.00195)$ & $(0.00109)$ & $(0.0155)$ & $(0.00809)$ & $(0.0105)$ & $(0.0132)$ \\
\hline \multirow[t]{2}{*}{2016} & $0.0209 *$ & 0.0148 & -0.00199 & -0.00231 & 0.0159 & 0.00708 & 0.00896 & 0.0145 \\
\hline & $(0.0107)$ & $(0.0105)$ & $(0.00183)$ & $(0.00134)$ & $(0.0125)$ & $(0.00848)$ & $(0.0140)$ & $(0.0162)$ \\
\hline \multirow[t]{2}{*}{2017} & 0.00659 & -0.000151 & $-0.00505^{*}$ & $-0.00471 * * *$ & 0.00265 & 0.00239 & $0.0293^{*}$ & 0.0299 \\
\hline & $(0.0111)$ & $(0.0135)$ & $(0.00281)$ & $(0.00157)$ & $(0.0158)$ & $(0.00768)$ & $(0.0157)$ & $(0.0180)$ \\
\hline Observations & 50 & 50 & 50 & 50 & 50 & 50 & 50 & 50 \\
\hline Groups & 16 & 16 & 16 & 16 & 16 & 16 & 16 & 16 \\
\hline $\mathrm{R}^{2}$ within & 0.781 & 0.734 & 0.697 & 0.701 & 0.728 & 0.618 & 0.754 & 0.741 \\
\hline $\mathrm{R}^{2}$ between & 0.0174 & 0.0643 & 0.234 & 0.0678 & 0.0862 & 0.259 & 0.437 & 0.380 \\
\hline $\mathrm{R}^{2}$ overall & 0.346 & 0.163 & 0.474 & 0.339 & 0.155 & 0.0317 & 0.00233 & 0.0186 \\
\hline
\end{tabular}

(4)

(5)

\begin{tabular}{|c|c|c|c|c|c|c|c|c|}
\hline & $\begin{array}{c}\text { Increase in } \\
\text { diagonal } \\
\text { inequality }\end{array}$ & $\begin{array}{l}\text { Increase in } \\
\text { vertical } \\
\text { inequality }\end{array}$ & $\begin{array}{l}\text { Increase in } \\
\text { horizontal } \\
\text { inequality }\end{array}$ & $\begin{array}{l}\text { Increase in } \\
\text { horizontal } \\
\text { inequality } \\
\text { (weighted) }\end{array}$ & $\begin{array}{l}\text { Increase in } \\
\text { ratio of vert. } \\
\text { and horiz. } \\
\text { ineq. }\end{array}$ & $\begin{array}{c}\text { Increase in } \\
\text { Gini } \\
\text { coefficient }\end{array}$ & $\begin{array}{l}\text { Average } \\
\text { growth } \\
\text { of salaries }\end{array}$ & $\begin{array}{l}\text { Average } \\
\text { growth } \\
\text { of salaries } \\
\text { (weighted) }\end{array}$ \\
\hline \multirow[t]{2}{*}{ Government ideology } & 0.00451 & 0.00299 & $-0.00280^{* *}$ & 0.00117 & 0.00411 & 0.00519 & 0.00681 & 0.00385 \\
\hline & $(0.00575)$ & $(0.00639)$ & $(0.00127)$ & $(0.000695)$ & $(0.00761)$ & $(0.00427)$ & $(0.00403)$ & $(0.00417)$ \\
\hline \multirow[t]{2}{*}{ Seat share government } & 0.0152 & 0.0220 & -0.00826 & $-0.00372 * *$ & 0.0246 & -0.0138 & -0.0198 & -0.00772 \\
\hline & $(0.0177)$ & $(0.0205)$ & $(0.00575)$ & $(0.00138)$ & $(0.0232)$ & $(0.0108)$ & $(0.0220)$ & $(0.0213)$ \\
\hline \multirow{2}{*}{$\begin{array}{l}\text { 1.Average age of } \\
\text { population }\end{array}$} & 0.00287 & 0.00262 & -0.000644 & 0.000127 & 0.00269 & 0.00299 & $-0.0156^{* *}$ & $-0.0128^{* *}$ \\
\hline & $(0.00565)$ & $(0.00604)$ & $(0.000662)$ & $(0.000483)$ & $(0.00589)$ & $(0.00384)$ & $(0.00547)$ & $(0.00599)$ \\
\hline \multirow{2}{*}{$\begin{array}{l}\text { 1.Increase in employee } \\
\text { salaries }\end{array}$} & 0.395 & 0.762 & 0.183 & 0.0716 & 0.736 & 0.0197 & -0.339 & -0.290 \\
\hline & $(0.405)$ & $(0.501)$ & $(0.112)$ & $(0.0422)$ & $(0.614)$ & $(0.329)$ & $(0.452)$ & $(0.498)$ \\
\hline \multirow{2}{*}{$\begin{array}{l}\text { 1.Increase in Gini of } \\
\text { employee salaries }\end{array}$} & 0.0712 & 0.0628 & $0.0413^{* * *}$ & $0.0334 * * *$ & 0.0413 & -0.0430 & -0.0572 & -0.0439 \\
\hline & $(0.0664)$ & $(0.0681)$ & $(0.0121)$ & $(0.00936)$ & $(0.0807)$ & $(0.0447)$ & $(0.0745)$ & $(0.0853)$ \\
\hline \multirow[t]{2}{*}{ 1.Increase in debt/GDP } & -0.00785 & -0.0286 & -0.00356 & -0.00722 & -0.0561 & 0.0120 & 0.0595 & 0.0510 \\
\hline & $(0.0728)$ & $(0.0744)$ & $(0.0130)$ & $(0.00893)$ & $(0.0767)$ & $(0.0455)$ & $(0.0528)$ & $(0.0602)$ \\
\hline \multirow{2}{*}{$\begin{array}{l}\text { 1.Increase in civil } \\
\text { servants p.c. }\end{array}$} & -0.258 & 0.0602 & $0.142^{*}$ & -0.0177 & 0.0369 & $-0.419 *$ & -0.0672 & 0.0532 \\
\hline & $(0.276)$ & $(0.239)$ & $(0.0726)$ & $(0.0397)$ & $(0.254)$ & $(0.211)$ & $(0.312)$ & $(0.341)$ \\
\hline \multirow{2}{*}{$\begin{array}{l}\text { 1.Dependent variable } \\
\text { federal }\end{array}$} & -0.140 & -0.369 & 0.196 & 0.00988 & -0.245 & 0.0172 & $0.556^{*}$ & 0.420 \\
\hline & $(0.384)$ & $(0.455)$ & $(0.112)$ & $(0.0372)$ & $(0.363)$ & $(0.0573)$ & $(0.288)$ & $(0.317)$ \\
\hline \multirow[t]{2}{*}{2008} & 0.0104 & 0.00381 & -0.000941 & -0.00145 & 0.0105 & 0.00888 & 0.0101 & 0.0117 \\
\hline & $(0.0172)$ & $(0.0174)$ & $(0.00298)$ & $(0.000921)$ & $(0.0164)$ & $(0.00957)$ & $(0.0136)$ & (0.0164) \\
\hline \multirow[t]{2}{*}{2009} & 0.0121 & 0.00953 & 0.00294 & $-0.00236^{* *}$ & 0.0163 & -0.00416 & 0.00436 & 0.00674 \\
\hline & $(0.0129)$ & $(0.0140)$ & $(0.00256)$ & $(0.00107)$ & $(0.00940)$ & $(0.00588)$ & $(0.0137)$ & $(0.0156)$ \\
\hline \multirow[t]{2}{*}{2010} & $0.0394^{*}$ & 0.0297 & -0.00491 & -0.000472 & $0.0403^{* *}$ & $0.0163^{*}$ & -0.0167 & -0.0173 \\
\hline & $(0.0189)$ & $(0.0204)$ & $(0.00363)$ & (0.000898) & $(0.0165)$ & $(0.00895)$ & $(0.0127)$ & $(0.0173)$ \\
\hline \multirow[t]{2}{*}{2011} & 0.0294 & 0.0193 & -0.00658 & -0.00171 & 0.0297 & 0.0108 & 0.000445 & 0.00176 \\
\hline & $(0.0230)$ & $(0.0241)$ & $(0.00457)$ & $(0.00102)$ & $(0.0193)$ & $(0.0125)$ & $(0.0140)$ & (0.0191) \\
\hline \multirow[t]{2}{*}{2012} & $0.0391 * * *$ & $0.0427 * *$ & -0.00313 & -0.00133 & $0.0472 * *$ & $0.0201 * *$ & -0.0157 & -0.00631 \\
\hline & $(0.0116)$ & $(0.0151)$ & $(0.00320)$ & (0.000913) & $(0.0164)$ & $(0.00831)$ & $(0.0160)$ & $(0.0161)$ \\
\hline \multirow[t]{2}{*}{2013} & 0.0139 & 0.00417 & $-0.00636^{*}$ & $-0.00506^{* *}$ & 0.00594 & 0.0103 & 0.0179 & 0.0206 \\
\hline & $(0.0127)$ & $(0.0115)$ & $(0.00323)$ & $(0.00224)$ & $(0.0155)$ & $(0.00810)$ & $(0.0156)$ & (0.0188) \\
\hline \multirow[t]{2}{*}{2014} & 0.0137 & 0.00232 & $-0.00566^{*}$ & $-0.00486^{* *}$ & 0.00472 & 0.00363 & $0.0282^{*}$ & 0.0307 \\
\hline & $(0.0162)$ & $(0.0182)$ & $(0.00294)$ & $(0.00180)$ & $(0.0198)$ & $(0.00908)$ & $(0.0160)$ & $(0.0201)$ \\
\hline \multirow[t]{2}{*}{2015} & 0.0264 & 0.0235 & $-0.00518^{* *}$ & $-0.00287^{* *}$ & 0.0271 & 0.00238 & 0.0173 & 0.0197 \\
\hline & $(0.0158)$ & $(0.0168)$ & $(0.00195)$ & $(0.00109)$ & $(0.0155)$ & $(0.00809)$ & $(0.0105)$ & $(0.0132)$ \\
\hline \multirow[t]{2}{*}{2016} & $0.0209 *$ & 0.0148 & -0.00199 & -0.00231 & 0.0159 & 0.00708 & 0.00896 & 0.0145 \\
\hline & $(0.0107)$ & $(0.0105)$ & $(0.00183)$ & $(0.00134)$ & $(0.0125)$ & $(0.00848)$ & $(0.0140)$ & $(0.0162)$ \\
\hline \multirow[t]{2}{*}{2017} & 0.00659 & -0.000151 & $-0.00505^{*}$ & $-0.00471 * * *$ & 0.00265 & 0.00239 & $0.0293^{*}$ & 0.0299 \\
\hline & $(0.0111)$ & $(0.0135)$ & $(0.00281)$ & $(0.00157)$ & $(0.0158)$ & $(0.00768)$ & $(0.0157)$ & $(0.0180)$ \\
\hline Observations & 50 & 50 & 50 & 50 & 50 & 50 & 50 & 50 \\
\hline Groups & 16 & 16 & 16 & 16 & 16 & 16 & 16 & 16 \\
\hline $\mathrm{R}^{2}$ within & 0.781 & 0.734 & 0.697 & 0.701 & 0.728 & 0.618 & 0.754 & 0.741 \\
\hline $\mathrm{R}^{2}$ between & 0.0174 & 0.0643 & 0.234 & 0.0678 & 0.0862 & 0.259 & 0.437 & 0.380 \\
\hline $\mathrm{R}^{2}$ overall & 0.346 & 0.163 & 0.474 & 0.339 & 0.155 & 0.0317 & 0.00233 & 0.0186 \\
\hline
\end{tabular}

Increase in Increase in
ratio of vert. and horiz. ineq.

(6)

(7)

(8)

Reference category of year dummies: 2007. Standard errors in parentheses. ${ }^{*} p<0.10,{ }^{* *} p<0.05,{ }^{* * *} p<0.01$ 
Table 7: Regression results. Including ideology dummies and fixed time effects. Fixed-effects model with standard errors robust to heteroskedasticity (Huber/White/sandwich standard errors)

(1)

Increase in diagonal inequality
(2)

Increase in vertical inequality
(3)

Increase in horizontal inequality
(4)

Increase in horizontal inequality (weighted)
(5)

Increase in Increase in ratio of vert. and horiz. ineq.
(7)

Average
growth
of salaries
(8)

Average growth of salaries (weighted)

\begin{tabular}{|c|c|c|c|c|c|c|c|c|}
\hline Ideology left & $\begin{array}{c}0.00460 \\
(0.00574)\end{array}$ & $\begin{array}{c}0.00302 \\
(0.00657)\end{array}$ & $\begin{array}{c}-0.00282^{*} \\
(0.00136)\end{array}$ & $\begin{array}{c}0.00117 \\
(0.000712)\end{array}$ & $\begin{array}{c}0.00419 \\
(0.00784)\end{array}$ & $\begin{array}{c}0.00518 \\
(0.00435)\end{array}$ & $\begin{array}{l}0.00679 \\
(0.00391)\end{array}$ & $\begin{array}{c}0.00387 \\
(0.00405)\end{array}$ \\
\hline \multirow[t]{2}{*}{ Ideology center } & 0.000212 & 0.000935 & -0.000409 & 0.000624 & 0.00113 & 0.00227 & 0.000213 & -0.00201 \\
\hline & $(0.00703)$ & $(0.00822)$ & $(0.00127)$ & $(0.000730)$ & $(0.00874)$ & $(0.00324)$ & $(0.00374)$ & $(0.00431)$ \\
\hline \multirow[t]{2}{*}{ Seat share government } & 0.0217 & 0.0238 & -0.0113 & -0.00385 & 0.0276 & -0.0128 & -0.00951 & 0.00533 \\
\hline & $(0.0297)$ & $(0.0367)$ & $(0.00650)$ & $(0.00267)$ & $(0.0384)$ & $(0.0157)$ & $(0.0277)$ & $(0.0281)$ \\
\hline \multirow{2}{*}{$\begin{array}{l}\text { 1.Average age of } \\
\text { population }\end{array}$} & 0.00222 & 0.00244 & -0.000405 & 0.000135 & 0.00238 & 0.00294 & $-0.0163 * * *$ & $-0.0138 * *$ \\
\hline & $(0.00530)$ & $(0.00604)$ & $(0.000710)$ & $(0.000444)$ & $(0.00582)$ & $(0.00389)$ & $(0.00493)$ & $(0.00548)$ \\
\hline \multirow{2}{*}{$\begin{array}{l}\text { 1.Increase in employee } \\
\text { salaries }\end{array}$} & 0.451 & 0.778 & 0.152 & 0.0705 & 0.761 & 0.0303 & -0.245 & -0.183 \\
\hline & $(0.384)$ & $(0.522)$ & $(0.0955)$ & $(0.0404)$ & $(0.623)$ & $(0.342)$ & $(0.437)$ & $(0.486)$ \\
\hline \multirow{2}{*}{$\begin{array}{l}\text { 1.Increase in Gini of } \\
\text { employee salaries }\end{array}$} & 0.0711 & 0.0627 & $0.0409^{* * *}$ & $0.0334 * * *$ & 0.0409 & -0.0428 & -0.0556 & -0.0424 \\
\hline & $(0.0673)$ & $(0.0691)$ & $(0.0120)$ & $(0.00949)$ & $(0.0829)$ & $(0.0458)$ & $(0.0780)$ & (0.0898) \\
\hline \multirow[t]{2}{*}{ 1.Increase in debt/GDP } & -0.00747 & -0.0285 & -0.00438 & -0.00722 & -0.0554 & 0.0122 & 0.0597 & 0.0500 \\
\hline & $(0.0710)$ & $(0.0748)$ & $(0.0124)$ & $(0.00914)$ & $(0.0776)$ & $(0.0462)$ & $(0.0509)$ & $(0.0570)$ \\
\hline \multirow{2}{*}{$\begin{array}{l}\text { 1.Increase in civil } \\
\text { servants p.c. }\end{array}$} & -0.286 & 0.0527 & $0.154^{*}$ & -0.0173 & 0.0219 & $-0.422^{*}$ & -0.101 & 0.00870 \\
\hline & $(0.260)$ & $(0.272)$ & $(0.0759)$ & $(0.0389)$ & $(0.290)$ & $(0.217)$ & $(0.311)$ & $(0.335)$ \\
\hline \multirow{2}{*}{$\begin{array}{l}\text { 1.Dependent variable } \\
\text { federal }\end{array}$} & -0.122 & -0.364 & $0.201 *$ & 0.00911 & -0.237 & 0.0163 & $0.543^{*}$ & 0.397 \\
\hline & $(0.377)$ & $(0.476)$ & $(0.109)$ & $(0.0403)$ & $(0.384)$ & $(0.0605)$ & $(0.295)$ & $(0.323)$ \\
\hline \multirow[t]{2}{*}{2008} & 0.0109 & 0.00395 & -0.000936 & -0.00146 & 0.0107 & 0.00892 & 0.0105 & 0.0126 \\
\hline & $(0.0173)$ & $(0.0182)$ & $(0.00285)$ & $(0.000950)$ & $(0.0172)$ & $(0.00979)$ & $(0.0139)$ & $(0.0168)$ \\
\hline \multirow[t]{2}{*}{2009} & 0.0130 & 0.00977 & 0.00278 & $-0.00238^{*}$ & 0.0166 & -0.00406 & 0.00541 & 0.00843 \\
\hline & $(0.0136)$ & $(0.0154)$ & $(0.00273)$ & $(0.00117)$ & $(0.0108)$ & $(0.00645)$ & $(0.0125)$ & $(0.0146)$ \\
\hline \multirow[t]{2}{*}{2010} & $0.0414 *$ & 0.0302 & -0.00557 & -0.000508 & $0.0411^{* *}$ & 0.0166 & -0.0139 & -0.0132 \\
\hline & $(0.0201)$ & $(0.0235)$ & $(0.00362)$ & $(0.000929)$ & $(0.0192)$ & (0.00997) & $(0.0122)$ & $(0.0164)$ \\
\hline \multirow[t]{2}{*}{2011} & 0.0305 & 0.0196 & -0.00676 & -0.00173 & 0.0302 & 0.0108 & 0.00191 & 0.00429 \\
\hline & $(0.0231)$ & $(0.0255)$ & $(0.00447)$ & $(0.000997)$ & $(0.0204)$ & $(0.0129)$ & $(0.0142)$ & $(0.0188)$ \\
\hline \multirow[t]{2}{*}{2012} & $0.0380 * * *$ & $0.0424^{* *}$ & -0.00265 & -0.00131 & $0.0466^{* *}$ & $0.0200^{* *}$ & -0.0165 & -0.00713 \\
\hline & $(0.0127)$ & $(0.0178)$ & $(0.00293)$ & $(0.000984)$ & $(0.0194)$ & $(0.00831)$ & $(0.0168)$ & $(0.0168)$ \\
\hline \multirow[t]{2}{*}{2013} & 0.0134 & 0.00403 & $-0.00599 *$ & $-0.00505^{* *}$ & 0.00583 & 0.0102 & 0.0171 & 0.0200 \\
\hline & $(0.0118)$ & $(0.0111)$ & $(0.00322)$ & $(0.00229)$ & $(0.0152)$ & $(0.00809)$ & $(0.0159)$ & (0.0195) \\
\hline \multirow[t]{2}{*}{2014} & 0.0145 & 0.00255 & $-0.00588^{*}$ & $-0.00487 * *$ & 0.00520 & 0.00367 & $0.0293^{*}$ & 0.0326 \\
\hline & $(0.0162)$ & $(0.0189)$ & $(0.00293)$ & $(0.00184)$ & $(0.0209)$ & $(0.00931)$ & $(0.0156)$ & (0.0197) \\
\hline \multirow[t]{2}{*}{2015} & 0.0277 & 0.0239 & $-0.00560^{* *}$ & $-0.00289 * *$ & 0.0277 & 0.00250 & $0.0191 *$ & 0.0223 \\
\hline & $(0.0172)$ & $(0.0184)$ & $(0.00226)$ & $(0.00113)$ & $(0.0174)$ & $(0.00865)$ & (0.00991) & $(0.0129)$ \\
\hline \multirow[t]{2}{*}{2016} & $0.0197 *$ & 0.0145 & -0.00136 & -0.00229 & 0.0154 & 0.00687 & 0.00748 & 0.0130 \\
\hline & $(0.0101)$ & $(0.0110)$ & $(0.00190)$ & $(0.00137)$ & $(0.0125)$ & $(0.00864)$ & $(0.0146)$ & $(0.0169)$ \\
\hline \multirow[t]{2}{*}{2017} & 0.00697 & -0.0000465 & $-0.00504^{*}$ & $-0.00471 * * *$ & 0.00291 & 0.00236 & $0.0296^{*}$ & 0.0308 \\
\hline & $(0.0112)$ & $(0.0139)$ & $(0.00286)$ & $(0.00159)$ & $(0.0166)$ & $(0.00772)$ & $(0.0155)$ & $(0.0179)$ \\
\hline Observations & 50 & 50 & 50 & 50 & 50 & 50 & 50 & 50 \\
\hline Groups & 16 & 16 & 16 & 16 & 16 & 16 & 16 & 16 \\
\hline $\mathrm{R}^{2}$ within & 0.783 & 0.734 & 0.709 & 0.701 & 0.728 & 0.618 & 0.759 & 0.748 \\
\hline $\mathrm{R}^{2}$ between & 0.0236 & 0.0668 & 0.243 & 0.0644 & 0.0909 & 0.261 & 0.440 & 0.388 \\
\hline $\mathrm{R}^{2}$ overall & 0.387 & 0.170 & 0.476 & 0.334 & 0.167 & 0.0337 & 0.00106 & 0.0111 \\
\hline
\end{tabular}

Reference category of year dummies: 2007. Standard errors in parentheses. $* p<0.10,{ }^{* *} p<0.05$, $* * * p<0.01$ 
Table 8: Percentage premia for cabinet members in the German states

\begin{tabular}{|c|c|c|c|}
\hline \multirow[t]{2}{*}{ State } & \multicolumn{2}{|c|}{ Percentage premium } & \multirow[t]{2}{*}{ Reforms 2007-2017 } \\
\hline & $\begin{array}{r}\text { Prime } \\
\text { minister }\end{array}$ & Minister ${ }^{b}$ & \\
\hline Baden-Wuerttemberg & $20.00(\mathrm{~B} 11)$ & $0.00(\mathrm{~B} 11)$ & - \\
\hline Bavaria & $28.00(\mathrm{~B} 11)$ & $18.75(\mathrm{~B} 11)$ & - \\
\hline Berlin & $20.00(\mathrm{~B} 11)$ & $0.00(\mathrm{~B} 11)$ & - \\
\hline Brandenburg & 9.00 (B11) & $0.00(\mathrm{~B} 11)$ & - \\
\hline Bremen & $0.00(\mathrm{~B} 11)$ & $0.00(\mathrm{~B} 11)$ & - \\
\hline Hamburg & $23.00(\mathrm{~B} 11)$ & $23.00(\mathrm{~B} 11)$ & - \\
\hline Hesse & $19.00(\mathrm{~B} 11)$ & $-0.77(\mathrm{~B} 11)$ & 2010 (decrease) \\
\hline Lower Saxony & $27.40(\mathrm{~B} 10)$ & $12.86(\mathrm{~B} 10)$ & - \\
\hline Mecklenburg-Western Pomerania & $10.00(\mathrm{~B} 11)$ & $10.00(\mathrm{~B} 10)$ & - \\
\hline North Rhine-Westphalia & $33.33(\mathrm{~B} 11)$ & $20.00(\mathrm{~B} 11)$ & - \\
\hline Rhineland-Palatinate & $13.49(\mathrm{~B} 10)$ & $3.77(\mathrm{~B} 10)$ & 2008 (decrease) \\
\hline Saarland & $10.00(\mathrm{~B} 11)$ & $0.00(\mathrm{~B} 11)$ & - \\
\hline Saxony & $20.00(\mathrm{~B} 11)$ & $0.00(\mathrm{~B} 11)$ & - \\
\hline Saxony-Anhalt & $10.00(\mathrm{~B} 11)$ & $0.00(\mathrm{~B} 11)$ & - \\
\hline Schleswig-Holstein & 4.80 (B11) & $4.80(\mathrm{~B} 10)$ & 2013 (decrease) \\
\hline Thuringia & $22.00(\mathrm{~B} 10)$ & $3.00(\mathrm{~B} 10)$ & 2008 (decrease), 2011 (increase) \\
\hline
\end{tabular}

a: In Berlin, Bremen, and Hamburg “(First/Governing) Mayor”. b: In Berlin, Bremen, and Hamburg "Senator".

Note: Percentage premia are paid on top of B10 or B11 salary. Source: own illustration 
Figure 1: Increases in inequality of civil servants' salaries: government ideology does not seem to matter
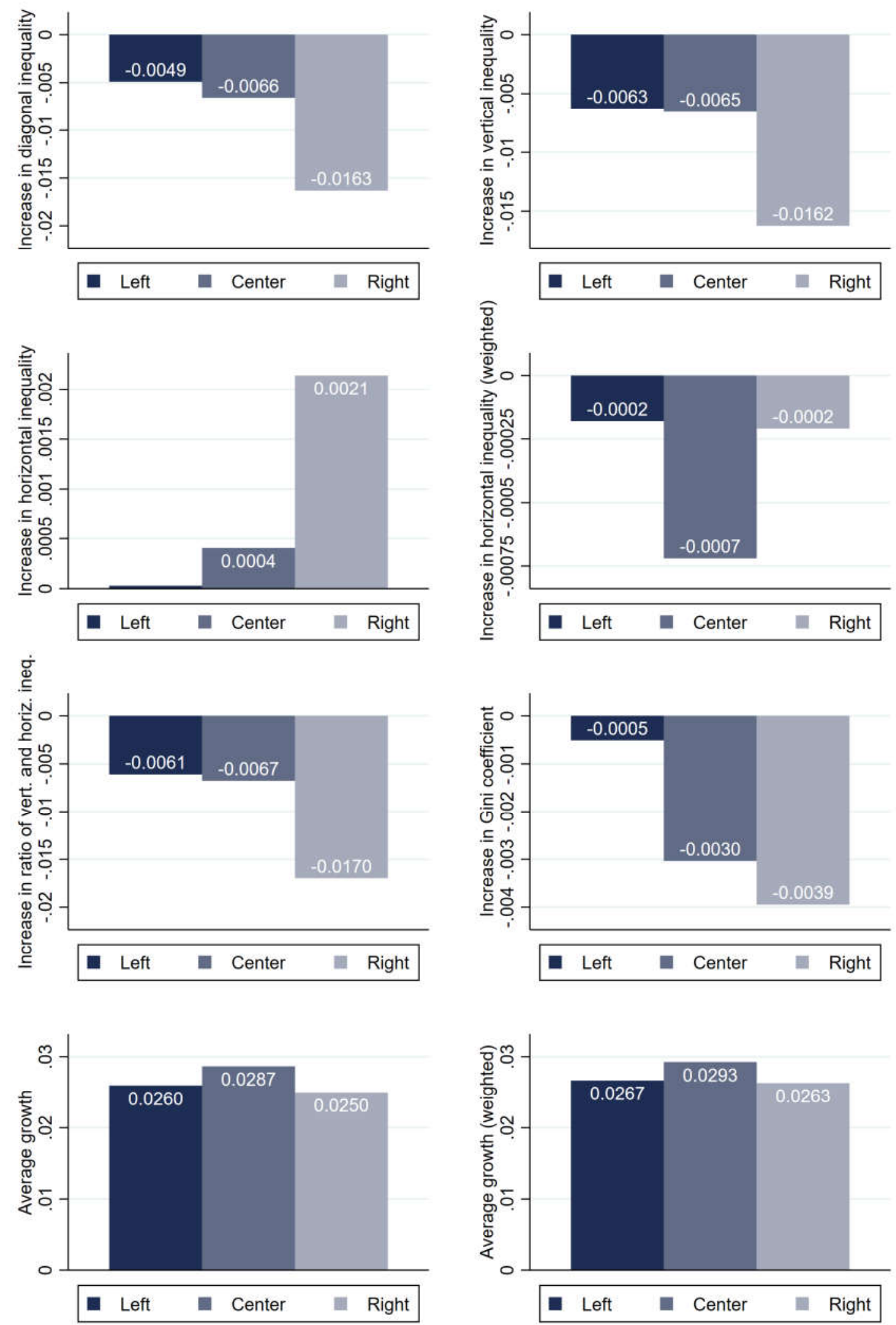